\title{
Problematika Perlindungan Hukum terhadap Produk Indikasi Geografis
}

\author{
Syarifa Mahila ${ }^{1}$ \\ 'Dosen Tetap Fakultas Hukum Universitas Batanghari \\ Correspondence email: mahila218@gmail.com
}

\begin{abstract}
Geographical Indications are legal protections that are regulated in TRIPs on goods or products based on the reputation, quality and characteristics of each region. IG is a separate Intellectual Property Rights which is different from other Intellectual Property Rights because IG can only be registered as a joint / communal right. Geographical Indications are regulated in one Act with a mark, namely Law Number 20 Year 2016 concerning Trademarks and Geographical Indications. IG is a communal right so that in the implementation of its protection it can cause various problems, both in terms of product marketing by external parties and by the IG owner community it self. In terms of supervision it can also cause problems because of the connection with the difficulty of conducting supervision because it involves many individuals with different interests and characters. IG arrangements must be sufficient to support local economic development efforts and even be able to compete globally.
\end{abstract}

Keyword: Geographical Indications; communal righs; legal protections.

\section{PENDAHULUAN}

Indikasi Geografis (selanjutnya disebut IG) merupakan suatu istilah geografis yang berkaitan dengan sebuah produk yang menunjukkan tempat atau daerah asal dan mutu produk yang berasal dari karakter geografis. Faktor geografis suatu daerah/wilayah tertentu dari suatu negara merupakan unsur penentu dalam membentuk kualitas, reputasi atau karakteristik tertentu dari suatu barang yang akan memperoleh perlindungan indikasi geografis. Keberadaan Indikasi geografis telah diakui sebagai bagian dari HKI semenjak ditandatanganinya persetujuan TRIPs pada tahun 1994. Sebelum TRIPs, indikasi geografis sudah dikenal dalam beberapa konvensi ataupun treaty meskipun tidak secara khusus menyebut istilah indikasi geografis, misalnya dalam the Paris Convention for the Protection of Industial Property ( Konvensi Paris), Madrid Agreement tahun 1891 yang telah direvisi tahun 1979 serta Lisbon Agreement tahun 1958 yang telah direvisi tahun 1979 (Djulaeka: 2014: 3-4). Perlindungan Indikasi Geografis jelas diatur dalam ketentuan TRIPs Article 22 sampai dengan 24. Pengaturan IG dalam TRIPs bertujuan untuk mencegah penggunaan IG yang salah dan berpotensi menyesatkan masyarakat, serta mencegah persaingan usaha tidak sehat ( curang ).

Dalam persetujuan TRIPs melarang kepada produsen untuk memakai label atau tanda (atau juga merek) terhadap barang yang diproduksinya tidak sesuai dengan IG. Misalnya mencantumkan label "Kopi Sidikalang " untuk kopi yang tidak diproduksi di Sidikalang. Atau menampilkan merek "Apel Washington" untuk apel yang dihasilkan dari daerah Brastagi (OK.Saidin:2015:494). Pada umumnya IG menampilkan nama produk dan nama daerah tempat produk IG dihasilkan.

Sebagai Negara yang menjadi anggota GATT, Indonesia terikat untuk mengikuti ketentuan-ketentuan yang ada pada GATT mengenai Indikasi Geografis. Adapun Indikasi Geografis dijelas pada TRIPs yang dahulu masih sangat kecil lingkupnya yakni pada bidang food geographical indications yang aturan itu terdapat pada Pasal 1 ayat (3) yang menyebutkan "defines industrial property to include all manufactures or natural products for example, wines, grape, tobacco leaf, fruit, cattle, minerals, minerals water, beer, flower and flour". Sama halnya dengan yang ada pada di Paris Conventian, Indikasi Geografis juga dinyatakan bahwa "the protection for industrial property includes" indications of source or appellation of origin" ( Umar Haris.S.: 2016:22).

Indonesia memiliki produk-produk yang berpotensi sebagai Indikasi Geografis. Seperti kita ketahui bahwa Indonesia kaya akan kekayaan alam tumbuhan yang menghasilkan produk-produk yang berbeda dari masing- masing daerah. Perbedaan tersebut disebabkan seperti faktor alam, faktor manusia dan daerah yang itu semua berpotensi memberikan ciri kualitas tertentu pada barang atau produk yang dihasilkan dan dapat mempunyai nilai ekonomi. Oleh karena itu Indonesia perlu untuk membuat peraturan tentang perlindungan Indikasi Geografis dengan harapan untuk memberikan perlindungan kepada masyarakat akan hasil kekayaan alamnya.

Pasal 53 ayat 3 UU Merek dan Indikasi Geografis (yang selanjutnya disebut UUMIG) bahwa IG dilindungi hukum setelah didaftarkan kepada Menteri Hukum dan HAM melalui permohonan yang dapat diajukan oleh: (a) lembaga yang mewakili masyarakat di kawasan geografis tertentu yang mengusahakan suatu barang dan/ atau produk, (b) Pemerintah daerah provinsi atau kabupaten/kota.

TRIPs menyatakan "for the purpose of this agreement' berarti, unsur-unsur definisi IG merupakan sifat khas yang berbeda dengan rezim $\mathrm{KI}$ lain. Setidaknya, ada empat unsur pokok IG dalam Perjanjian TRIPs, yaitu, pertama, unsur nama geografis untuk mengidentifikasi, tidak bersifat mutlak karena dapat menggunakan nama Nomorn-geografis; kedua, unsur wilayah dalam negara sebagai tempat produksi tidak identik dengan wilayah administratif namun disesuaikan dengan kondisi faktual; ketiga, unsur kepemilikan dalam IG bukan merupakan hak individual (private right) tetapi hak komunal (communal right), maka IG merupakan hak untuk menggunakan (right to use); dan keempat, unsur kualitas, reputasi, atau karakteristik lain yang bersifat alternatif, sehingga barang / produk sudah cukup memenuhi salah satu dari unsur tersebut ( Wahyu.S.: 2008:107-108). 
Pasal 66 Undang-Undang Nomor 20 Tahun 2016 ( UUMIG ) menjelaskan Pelanggaran atas IG mencakup: a. pemakaian IG, baik secara langsung maupun tidak langsung atas barang dan/atau produk yang tidak memenuhi Dokumen Deskripsi IG; b. pemakaian suatu tanda IG, baik secara langsung maupun tidak langsung atas barang dan/atau produk yang dilindungi atau tidak dilindungi dengan maksud untuk: 1. menunjukkan bahwa barang dan/atau produk tersebut sebanding kualitasnya dengan barang dan/atau produk yang dilindungi oleh IG; 2. mendapatkan keuntungan dari pemakaian tersebut; atau 3. mendapatkan keuntungan atas reputasi IG c. pemakaian IG yang dapat menyesatkan masyarakat sehubungan dengan asal-usul geografis barang itu; d. pemakaian IG oleh bukan pemakai IG terdaftar; e. peniruan atau penyalahgunaan yang dapat menyesatkan sehubungan dengan asal tempat barang dan/atau produk atau kualitas barang.

Jika dilihat dari beberapa ketentuan yang diatur dalam peraturan perundang-undangan yang diuraikan diatas, bahwa IG merupakan HKI yang dimiliki secara komunal, jadi bukan hak individu. Karena merupakan hak komunal yang dimiliki secara bersama oleh lembaga ataupun masyarakat suatu daerah, maka dapat menimbulkan permasalahan dari berbagai aspek, seperti tentang hak penggunaan nama produk untuk keuntungan ekonomi, kewajiban memelihara kualitas dan ciri khusus produk atau barang dan berbagai persoalan lainnya. Berdasarkan permasalahan tersebut perlu dikaji lebih lanjut tentang pengaturan IG dalam bentuk penelitian karya ilmiah dengan judul : Problematika Perlindungan Hukum Terhadap Produk Indikasi Geografis .

\section{Rumusan Masalah}

Berdasarkan pengantar dalam pendahuluan tersebut, maka dapat ditarik suatu permasalahan yaitu bagaimana problematika perlindungan hukum terhadap produk hasil Indikasi Geografis.

\section{PEMBAHASAN \\ Pengertian Indikasi Geografis}

Undang-Undang Nomor 20 Tahun 2016 tentang Merek dan Indikasi Geografis Pasal 1 Angka 6 memberikan defenisi "IG adalah suatu tanda yang menunjukkan daerah asal suatu barang dan/atau produk yang karena faktor lingkungan geografis termasuk faktor alam, faktor manusia atau kombinasi dari kedua faktor tersebut memberikan reputasi, kualitas, dan karakteristik tertentu pada barang dan/atau produk yang dihasilkan. Yang dimaksud tanda dalam definisi IG tersebut adalah nama tempat atau daerah maupun tanda tertentu lainnya yang menunjukkan asal tempat dihasilkannya suatu barang yang dilindungi oleh IG, dapat berupa hasil pertanian, produk olahan, hasil kerajinan atau barang lainnya.

Tanda yang digunakan sebagai IG dapat berupa etiket atau label yang dilekatkan pada barang yang dihasilkan. Tanda tersebut dapat berupa nama tempat, daerah, atau wilayah, kata, gambar, huruf atau kombinasi dari unsur-unsur tersebut. Pengertian nama tempat dapat berasal dari nama yang tertera dalam peta geografis, atau nama yang karena pemakaian secara terus menerus sehingga dikenal sebagai nama tempat asal barang yang bersangkutan. Perlindungi IG meliputi barang-barang yang dihasilkan oleh alam, barang hasil pertanian, hasil kerajinan tangan, atau hasil industri tertentu lainnya ( olahan manusia dari barang mentah menjadi barang jadi seperti tenun Sikka, tenun Grinsing ( Khoirul H: 2018:63). Contoh tanda berupa kata misalnya kata " Minang " mengindikasikan daerah Sumatera Barat, gambar rumah adat Toraja, mengindikasikan daerah Toraja. Hak atas IG adalah hak eksklusif yang diberikan oleh negara kepada pemegang hak IG yang terdaftar, selama reputasi, kualitas, dan karakteristik yang menjadi dasar diberikannya perlindungan atas IG tersebut masih ada ( Pasal 1 angka 7 UUMIG ). Pasal 1 Angka 10 menjelaskan bahwa pemakai IG adalah pihak yang mendapat izin dari pemegang hak IG yang terdaftar untuk mengolah atau memasarkan barang atau produk IG.

Pasal 56 UUM memberikan pembatasan bahwa permohonan pendaftaran IG tidak dapat diajukan jika bertentangan dengan peraturan perundang-undangan , moralitas agama, kesusilaan atau ketertiban umum. Menyesatkan atau memberdaya masyarakat mengenai ciri, sifat, kualitas, asal sumber, proses pembuatan barang atau kegunaannya. Nama geografis setempat yang telah digunakan sebagai nama varietas tanaman seperti kata "Cianjur" telah dikenal sebagai nama salah satu varietas tanaman padi, maka kata Cianjur tidak boleh digunakan untuk IG tanaman padi varietas lainnya walaupun dibudidayakan di Cianjur. Telah menjadi generik yaitu suatu barang yang telah menjadi milik umum karena sering digunakan dalam bahasa seharihari seperti tahu, tempe,jeruk bali, pisang ambon, dan sebagainya. IG tidak sama dengan Indikasi Asal sebagaimana diatur dapa pasal 63-64 UUMIG. Indikasi Asal hanya berkaitan dengan asal barang di produksi yang tidak terkait dengan faktor alam. Contoh Indikasi Asal , label Made in China untuk merek Nikon yang diproduksi berdasarkan lisensi oleh pabrik yang berada di China walaupun merek tersebut berasal dari Jepang. Indikasi Asal tidak perlu dilakukan pendaftaran, karena mereknya sendiri sudah terdaftar dan diproduksi berdasarkan perjanjian lisensi.

Indikasi geografis memberikan perlindungan terhadap tanda yang mengidentifikasikan suatu wilayah negara, atau kawasan atau daerah didalam wilayah tersebut sebagai asal barang, dimana reputasi, kualitas dan karakteristik barang tersebut sangat ditentukan oleh faktor geografis yang bersangkutan. Ciri dan kualitas barang yang dipelihara dan dapat dipertahankan dalam jangka waktu tertentu akan melahirkan reputasi atas barang tersebut, yang selanjutnya memungkinkan barang tersebut memiliki nilai ekonomi tinggi (Siti Asyfiah :2015:113).

IG yang dilindungi tentu saja IG yang sudah terdaftar. Pasal 53 ayat (3) menentukan bahwa permohonan pendaftaran IG dapat dilakukan :

a lembaga yang mewakili masyarakat di kawasan geografis tertentu yang mengusahakan suatu barang dan/atau produk berupa:

(1) sumber daya alam;

(2) barang kerajinan tangan; atau

(3) hasil industri; 
b. pemerintah daerah provinsi atau kabupaten/kota.

Menurut penjelasan Pasal 53 ayat 3 UUMIG bahwa Lembaga yang mewakili masyarakat di kawasan geografis tertentu antara lain asosiasi produsen, koperasi, dan Masyarakat Perlindungan Indikasi Geografis (MPIG). Lebih lanjut dapat dijelaskan bahwa lembaga yang mewakili masyarakat di daerah yang memproduksi barang yang bersangkutan yaitu terdiri atas :

(1) pihak yang mengusahakan barang yang merupakan hasil alam atau kekayaan alam.

(2) Produsen barang hasil pertanian.

(3) Pembuat barang-barang kerajinan tangan atau hasil industri.

(4) Pedagang yang menjual barang tersebut (Khoirul.H.: 2018:63).

Pada penjelasan Pasal 1 Peraturan Pemerintah Nomor 51 Tahun 2007 Tentang Indikasi Geografis disebutkan bahwa pendaftaran Indikasi Geografis adalah untuk menjamin kepastian hukum dimana jangka waktu perlindungannya tidak terbatas selama ciri dan atau kualitas yang menjadi dasar diberikannya perlindungan masih ada. IG yang terdaftar tidak dapat berubah menjadi milik umum.

Contoh IG yang sudah terdaftar pada Dirjen HKI antara lain:

(1) Beras Adan Krayan yang diajukan oleh Asosiasi Masyarakat Adan Krayan Kabupaten Nunukan Kalimantan Timur.

(2) Susu Kuda Sumbawa yang didaftarkan oleh Asosiasi Pengembangan Susu Kuda Sumbawa Kabupaten Dompu pada tahun 2011.

(3) Kopi Kintamani Bali diajukan pendaftarannya oleh Masyarakat Perlindungan Indikasi Geografis (MPIG) Kecamatan Kintamani Kabupaten Badung dan beberapa kecamatan di Kabupaten Buleleng pada tahun 2008 (Khoirul.H.: 2018: 64).

Undang-Undang Nomor 20 Tahun 2016 tentang Merek dan Indikasi Geografis (UUMIG) merupakan penyempurnaan dari Undang-Undang Nomor 15 Tahun 2001 tentang Merek. UUMIG mengatur tentang pengertian, pendaftaran, pelanggaran IG dan lain-lain, sedangkan tata cara pendaftaran secara rinci diatur lebih lanjut dengan Peraturan Menteri.

\section{Problematika Perlindungan Hukum Produk Indikasi Geografis}

Tuntutan adanya perlindungan terhadap IG dalam sistem hukum KI adalah upaya untuk melindungi produkproduk masyarakat lokal dalam negeri karena merek yang dipakai oleh pelaku bisnis untuk memperkenalkan produk, biasanya menggunakan nama tempat atau lokasi geografis yang menjelaskan dari mana barang tersebut berasal. Lahirnya Undang-Undang Nomor 20 Tahun 2016 sebagai implementasi dari ketentuan Internasional mengatur IG secara lebih komprehensif daripada Undang-Undang Nomor 15 Tahun 2001 tentang Merek, diharapkan dapat memberikan kepastian hukum dalam mengembangkan potensi IG yang bernilai ekonomi tinggi, sehingga Undang-Undang tersebut diharapkan memiliki implikasi positif terhadap pengembangan ekonomi lokal dan mendorong kesadaran masyarakat / pemerintah daerah untuk mendaftarkannya. Perlindungan hukum IG menjadi penting untuk diperhatikan oleh Pemerintah daerah karena hak IG melahirkan hak ekslusif dan manfaat ekonomi bagi pemegangnya, serta memiliki potensi dalam peningkatan perekonomian daerah dan nasional.

IG dalam negeri yang terdaftar pertama adalah Kopi Arabika Kintamani Bali yang dimohonkan oleh kelompok tani atau yang sering disebut dengan Masyarakat Perlindungan Indikasi Geografis disebut dengan (MPIG) pada tahun 2005 dan ditetapkan sebagai produk IG pada tahun 2008 (Imam L:2018:315).

Pasal 66 Undang-Undang Nomor 20 Tahun 2016 menjelaskan Pelanggaran atas IG mencakup:

a. Pemakaian IG, baik secara langsung maupun tidak langsung atas barang dan/atau produk yang tidak memenuhi Dokumen Deskripsi IG;

b. Pemakaian suatu tanda IG, baik secara langsung maupun tidak langsung atas barang dan/atau produk yang dilindungi atau tidak dilindungi dengan maksud untuk:

(1) menunjukkan bahwa barang dan/atau produk tersebut sebanding kualitasnya dengan barang dan/atau produk yang dilindungi oleh IG;

(2) mendapatkan keuntungan dari pemakaian tersebut; atau

(3) mendapatkan keuntungan atas reputasi IG

c. Pemakaian IG yang dapat menyesatkan masyarakat sehubungan dengan asal-usul geografis barang itu;

d. Pemakaian IG oleh bukan pemakai IG terdaftar;

e. Peniruan atau penyalahgunaan yang dapat menyesatkan sehubungan dengan asal tempat barang dan/atau produk atau kualitas barang dan/atau produk yang terdapat pada:

(1) pembungkus atau kemasan;

(2) keterangan dalam iklan;

(3) keterangan dalam dokumen mengenai barang dan/atau produk tersebut;

(4) informasi yang dapat menyesatkan mengenai asal-usulnya dalam suatu kemasan

f. Tindakan lainnya yang dapat menyesatkan masyarakat luas mengenai kebenaran asal barang dan/atau produk tersebut.

Pengawasan IG dilakukan oleh pemerintah pusat dan pemerintah daerah sesuai dengan kewenangannya tetapi pengawasan dapat pula dilakukan oleh masyarakat. Pengawasan dilakukan untuk menjamin tetap adanya reputasi, kualitas, dan karakteristik yang menjadi dasar diterbitkannya IG dan mencegah penggunaan IG secara tidak sah. Hasil disampaikan kepada pemegang hak IG dan/atau Menteri. Pengaturan tentang pembinaan dan pengawasan penting dari sisi manajemen perlindungan IG karena pembinaan adalah usaha, tindakan, dan kegiatan yang berupa pendidikan maupun pelatihan yang dilakukan secara efisien dan efektif untuk memperoleh hasil yg lebih baik.

Objek IG melekat sebagai suatu property yang memiliki nilai ekonomis yang bukan merupakan karya intelektual yang dihasilkan oleh seseorang, tetapi lebih merupakan karena pengaruh faktor lingkungan geografis 
( unsur alam \& manusia ) yang memberikan karakteristik khusus pada barang yang dihasilkan oleh suatu daerah/wilayah. Peter Drahos menyatakan bahwa property adalah hak yang menghubungkan seseorang dengan orang lain atau seseorang dengan banyak orang. Property dapat dimiliki secara berkelompok/bersama yang dikenal dengan istilah common property. Konsep common property memiliki spektrum luas dan bervariasi yang dapat dipengaruhi oleh struktur alam ataupun struktur internal yang merupakan suatu unit sosial dengan keanggotaan dan batas wilayah yang jelas, dengan kepentingan bersama, dengan interaksi diantara anggota kelompok, dengan norma budaya yang secara umum terbentuk sebagai sistem kewenangan mereka sendiri (Djulaeka: 2014:7172).

Karakteristik common property pada objek perlindungan IG dapat dipahami bahwa kepemilikan IG merupakan pengakuan keberadaan adanya hak komunal bagi pihak yang berkepentingan di suatu daerah baik masyarakatnya maupun pemerintah daerah. Pengakuan adanya hak tentu harus sejalan dengan adanya kewajiban untuk mempertahankan dan melindungi hak tersebut. Objek IG berbasis common property ( hak milik kelompok ), sehingga keberadaan kelompok memiliki peran utama untuk melindungi produk IG. Kepemilikan komunal IG melibatkan pihak yang berkepentingan sekaligus sebagai pihak pengguna yang berhak memanfaatkan barang atau produk berbasis IG. Perlindungan IG dapat memberikan manfaat bagi pihak yang berkepentingan khususnya di daerah antara lain :

(1) Memperjelas identifikasi produk dan menetapkan standar proses diantara para pemangku kepentingan IG.

(2) Menghindari terjadinya praktek persaingan curang dalam perdagangan, memberikan perlindungan bagi konsumen dari penyalahgunaan reputasi IG dengan cara menjual produk yang berasal dari daerah lain yang memiliki karakteristik berbeda bahkan lebih rendah.

(3) Jaminan pada kualitas produk yang dilindungi IG sebagai produk asli memberikan kepercayaan pada konsumen (Djulaeka:2014: 141).

Dari beberapa manfaat yang disebutkan diatas dapat disimpulkan bahwa manfaat yang utama pemberian perlindungan IG yaitu sebagai identitas produk, menghindari persaingan curang dan memberikan kepercayaan kepada konsumen, hal tersebut senada dengan pelanggaran IG yang diatur pada pasal 66 UUMIG yang secara langsung juga merupakan perlindungan terhadap pemegang IG.

Sebagaimana telah dijelaskan terdahulu bahwa IG merupakan hak milik bersama dari kelompok /masyarakat/ pemerintah daerah yang mengajukan pendaftarannya yang juga mempunyai kewajiban untuk melindungi barang/produk IG baik dari segi kualitas, reputasi yang persyaratkan oleh peraturan perundangundangan maupun terhadap pelaku persaingan curang dalam perdagangan. IG merupakan milik bersama yang harus dijaga secara bersama juga, sehingga tidak menutup kemungkinan menimbulkan berbagai problem dalam menjaga barang/produk IG. Menurut pendapat penulis, problem tersebut dapat datang dari pihak luar seperti pedagang yang mendistribusikan produk IG tersebut, maupun datang dari masyarakat pemilik IG itu sendiri.

Problem yang datang dari pihak luar misalnya pedagang yang memasarkan produk IG di luar daerah, kemudian karena disebabkan berbagai faktor, mereka mencampur produk IG yang sudah terdaftar dengan produk lain yang sejenis yang kualitasnya yang lebih rendah, yang tentu hal ini dapat mengurangi kualitas produk secara keseluruhan. Persoalan ini sangat mudah terjadi pada produk IG yang pemasaranya tidak bisa dikemas utuh seperti duku, durian, ubi, jeruk, dan lainnya dengan persoalan serupa. Apabila terjadi hal seperti diatas yang sudah barang tentu sulit untuk dilakukan pengawasan. Kecurangan serupa dapat juga terjadi dilakukan oleh kelompok masyarakat pemegang IG itu sendiri yang memasarkan produk IG di daerahnya, kemudian karena berbagai faktor, mereka mencampurnya dengan produk serupa dari daerah lain yang kualitasnya tentu saja lebih rendah. Kecurangan yang kemungkinan dilakukan oleh pedagang maupun oleh oknum masyarakat pemegang hak IG sebagaimana diuraikan diatas, bukan saja merugikan kelompok masyarakat pemegang IG tetapi juga merugikan konsumen. Kecurangan tersebut dapat menurunkan reputasi produk IG. Jika kualitas dan reputasi produk IG menurun atau tidak sesuai lagi dengan kondisi pada waktu pendaftaran, maka hak IG dapat hapus sebagaimana diatur pada Pasal 66 UUMIG :

(1) Indikasi Geografis dilindungi selama terjaga reputasi, kualitas dan karakteristik yang menjadi dasar diberikannya perlindungan Indikasi Geografis pada suatu barang.

(2) Indikasi Geografis dapat hapus jika:

a. tidak dipenuhinya ketentuan sebagaimana dimaksud pada ayat (1).

b. melanggar ketentuan sebagaimana dimaksud dalam pasal 56 ayat (1) huruf a.

Pasal 62 mengatur bahwa selain tim ahli IG, masyarakat dapat juga melakukan penelitian terhadap reputasi, kualitas dan karakteristik IG terdaftar, jika tidak sesuai atau menurun maka dapat diajukan kepada menteri untuk dihapus. Masyarakat yang dimaksud pada ayat ini tidak disebutkan masyarakat yang mana, sehingga ada kemungkinan masyarakat yang dimaksud adalah masyarakat sebagai konsumen. Apabila konsumen sudah tidak mengakui reputasi dari produk $I G$, tentu hal ini sangat berpengaruh kepada nilai ekonomis dari produk IG tersebut, sementara tujuan didaftarnya produk IG adalah untuk meningkatkan nilai ekonomi produk tersebut.

Pengaturan IG harus memadai agar mendukung upaya pengembangan ekonomi lokal bahkan dapat bersaing secara global. Upaya selanjutnya untuk melindungi produk IG yaitu dilakukan pengawasan sebagaimana diatur pada pasal 71 UUMIG bahwa pengawasan IG dilakukan oleh pemerintah pusat dan daerah sesuai kewenangannya dan dapat juga dilakukan oleh masyarakat, guna untuk menjamin reputasi dan kualitas serta karakteristik dasar diterbitkannya IG serta mencegah penggunaan IG secara tidak sah. Pelaksanaan pengawasan tidak 
mudah walaupun sudah ada pengaturannya, namun dalam prakteknya juga dapat menimbulkan berbagai persoalan, apalagi IG ini merupakan hak milik bersama / hak komunal yang melibatkan banyak individu dengan karakter dan kepentingan yang berbeda.

Pasal 69 UUMIG mengatur bahwa pemegang hak IG dapat mengajukan gugatan permohonan ganti rugi terhadap pihak yang menggunakan label IG tanpa hak. Penggunaan IG tanpa hak merupakan perbuatan melanggar hukum karena menimbulkan kerugian bagi pihak pemegang hak IG sebagaimana dirumuskan pada pasal 1365 KUHPerdata : Tiap perbuatan yang melanggar hukum dan membawa kerugian kepada orang lain, mewajibkan kepada orang yang menimbulkan kerugian karena kesalahannya untuk mengganti kerugian. Disini siapa yang menuntut pengganti kerugian yang disebabkan karena sesuatu perbuatan yang melanggar hukum, harus membuktikan adanya kesalahan (Koesparmono I:2016:26). Dengan demikian untuk mengajukan permohonan ganti rugi, pemegang hak IG harus dapat membuktikan bahwa sudah terjadi perbuatan melanggar hukum yang menimbulkan kerugian. Pembuktian ini juga menjadi problem ketika pemasaran produk dilakukan di luar daerah. Pembuktian sulit juga dilakukan terhadap pencampuran produk IG dengan jenis produk yang sama tetapi kualitas lebih rendah karena sulit untuk dibedakan dengan kasat mata.

\section{SIMPULAN}

Indikasi Geografis merupakan perlindungan hukum yang diatur didalam TRIPs terhadap barang atau produk berdasarkan reputasi, kualitas dan karakteristik tersendiri dari suatu daerah/wilayah. IG merupakan HKI tersendiri yang berbeda dengan HKI lainya karena IG hanya dapat didaftarkan sebagai hak bersama/ komunal. Didalam Hukum Indonesia, Indikasi Geografis diletakkan didalam satu Undang-Undang bersama dengan merek yaitu Undang-Undang nomor 20 Tahun 2016 tentang Merek dan Indikasi Geografis.

IG merupakan hak komunal sehingga dalam pelaksanaan perlindungannya dapat menimbulkan berbagai problema, baik dari segi pemasaran produk maupun dari segi pengawasan. Pengaturan IG harus memadai agar mendukung upaya pengembangan ekonomi lokal bahkan dapat bersaing secara global.

\section{DAFTAR PUSTAKA}

Djulaeka (2014), Konsep Perlindungan Hak Kekayaan Intelektual Perspektif Kajian Filosofis Hak Kolektif-Komunal, Malang, Setara Press.

Khoirul Roisah (2015), Konsep Hukum Hak Kekayaan Intelektual ( Sejarah, pengertian dan Filosofi pengakuan HKI dari masa kemasa), Malang, Setara Press.

Koesparmono Irsan \& Armansyah (2016), Panduan Memahami Hukum Pembuktian dalam Hukum Perdata dan Hukum Perdata, Jakarta, Gramata Publishing.

Khoirul Hidayah (2018), Hukum Hak Kekayaan Intelektual, Malang , Setara Press.

OK.Saidin (2015), Aspek Hukum Hak Kekayaan Intelektual (Intellectual Property Rights), Jakarta, Raja Grafindo Persada.

\section{Peraturan Perundang-undangan}

Kitab Undang-Undang Hukum Perdata.

Undang-Undang Nomor 20 Tahun 2016 tentang Merek dan Indikasi Geografis.

Peraturan Pemerintah Nomor 51 Tahun 2007 Tentang Indikasi Geografis

\section{Jurnal}

Imam Lukito, Peran Pemerintah Daerah Dalam Mendorong Potensi Indikasi Geografis ( Studi pada Provinsi Kepulauan Riau), JIKH, Vol.12 No.3 November 2018: 313-330.

Siti Asfiyah, Perlindungan Hukum Potensi Indikasi Geografia di Kabupaten Brebes Guna Pengembangan Ekonomi Masyarakat Lokal, Jurnal Idea Hukum Vol.1 No.2 Edisi Oktober 2015 : 112-124.

Umar Haris Sanjaya, Problematik Penerapan UndangUndang Hak Kekayaan Intelektual Tentang Indikasi Geografik Pada Undang- Undang Merek, Jurnal Panorama Hukum Vol.1 No.2 Desember 2016: 17-28.

Wahyu Sasongko, Indikasi Geografis: Rezim HKI Yang Bersifat Sui Generis, Jurnal Media Hukum, 2008, hlm. 107-108. 